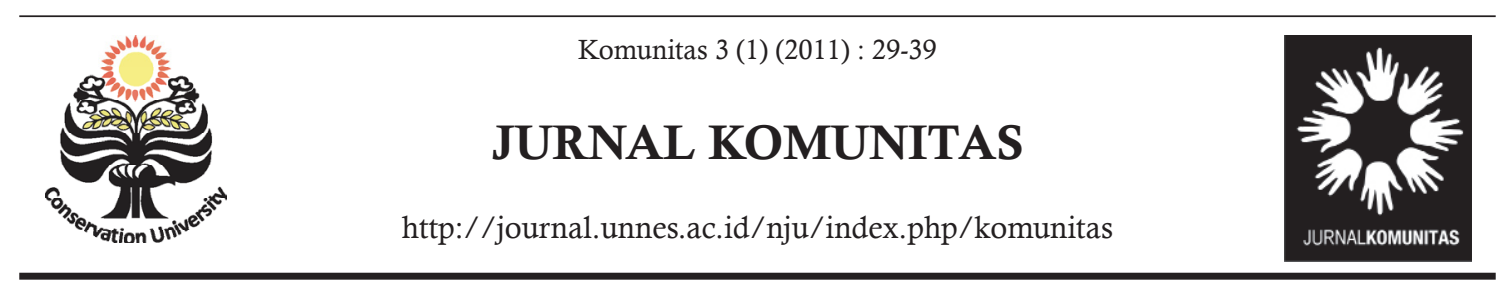

\title{
PERSEPSI MASYARAKAT SEKARAN TENTANG KONSERVASI LINGKUNGAN
}

\author{
Asma Luthfi, Atika Wijaya ${ }^{凶}$ \\ Jurusan Sosiologi dan Antropologi, Fakultas Ilmu Sosial, Universitas Negeri Semarang, Indonesia
}

\section{Info Artikel}

Sejarah Artikel:

Diterima Desember 2010

Disetujui Januari 2011

Dipublikasikan Maret 2011

Keywords:

environmental conservation; perception;

society.

\begin{abstract}
Abstrak
Isu konservasi lingkungan menjadi sebuah studi yang menarik belakangan ini karena efek dari global warming sudah semakin dirasakan oleh manusia. Kebijakan nasional dan international dengan perspektif konservasi lingkungan semakin dikuatkan, begitu pula dengan Unnes dengan visi kampus konservasinya. Selain kebijakan tersebut, komunitas lokal sebenarnya memiliki persepsi sendiri tentang konservasi lngkungan dari sistem nilai dan pengetahuannya. Tujuan penelitian ini adalah melihat persepsi masyarakat tentang konservasi lingkungan dan penerapan persepsi dalam aktivitas masyarakat. Metode yang digunakan adalah kuliatatif untuk memperoleh data yang akurat dan valid. Hasil penelitian menunjukkan persepsi masyarakat tentang konservasi lingkungan tidak dapat dipisahkan dari aktivitas masyarakat sebagai petani. Tingkat ketergantungan pada lingkungan membentuk persepsi akan konservasi melekat pada pola hidup keseharian mereka. Tapi persepsi tersebut berubah seiring dengan perubahan sosial di masyarakat. Interaksi antara msyarakat Sekaran dengan mahasiswa sebagai pendatang mendorong perubahan pandangan tentang alam dan mata pencaharian. Ketika sistem mata pencaharian mereka tidak lagi tergantung sepenuhnya pada manajemen sumber daya alam, begitu pula percepsi akan konservasi lingkungan turut berubah. Hal ini dibuktikan dengan pola aktivitas mereka yang tidak lagi berkomitmen sepenuhnya pada konservasi lingkungan. Ritual kolektif yang dahulu berfungsi untuk pemeliharaan lingkungan, kini digantikan oleh aktivitas personal dengan makna yang sempit.
\end{abstract}

\begin{abstract}
The issue of environmental conservation is an interesting study nowadays because the effect of global warming has been felt by mankind. Many national and international policies that toward environmental conservation perspective is encouraged, so did Unnes with its vision of conservation. Besides these policies, local communities actually have a perception about environmental conservation from their values and knowledge systems. The aim of this research is to find out society perception about environment conservation and the appearance of perception on the daily activities of the society. The research method is qualitative to gain accountable and valid data. Perceptions of environmental conservation can not be separated from their activities as farmers. The level of dependency on environtment makes perception of conservation is embedded well within the pattern of their daily lives. But this perception has shifted in line with social changes that occur. The presence of Unnes in their territory is the main factor of social changes in society. Interaction between Sekaran society with students as immigrant helped change their views about the nature and the occupation system. When the occupation system no longer depend entirely on the management of natural resources, so the perception of environmental conservation also shifted. This can be seen on their activity patterns that no longer has a full commitment to environmental conservation. Communal ritual that used to function as a place of transformation values of environmental conservation has been replaced with the personal activities of environmental hygiene has a narrower meaning.
\end{abstract}

(C) 2011 Universitas Negeri Semarang 


\section{PENDAHULUAN}

Pemanasan global (global warming) yang melanda masyarakat dunia saat ini merupakan masalah yang sangat krusial dan mendapatkan perhatian yang serius oleh negara-negara di dunia, baik negara maju maupun negara berkembang. Hal ini karena dampak global warming tidak hanya mengancam satu negara saja, tetapi menjadi ancaman bagi keberlangsungan hidup seluruh masyarakat dunia.

Fenomena global warming ini sesungguhnya berawal dari kerusakan ekologis yang terjadi di berbagai belahan dunia akibat perilaku manusia modern yang tidak lagi mempertimbangkan keseimbangan alam dan melakukan eksploitasi sumber daya alam secara ekstraktif. Seperti halnya yang terjadi di Indonesia, kerusakan lingkungan telah terjadi di hampir seluruh penjuru nusantara. Meski merupakan salah satu negara yang memiliki hutan tropis terbesar dan menjadi paru-paru dunia, tetapi aktifitas manusia yang eksploitatif dan merusak lingkungan tidak dapat terhindarkan. Kondisi ini menyebabkan terjadinya beragam bencana alam, seperi banjir bandang, tanah longsor, kekeringan, dan rob.

Mencermati fenomena ini, maka Pemerintah Republik Indonesia menggalakkan sebuah konsep pembangunan yang berwawasan lingkungan dan berkelanjutan. Konsep pembangunan yang berwawasan lingkungan ini dimaksudkan agar pelaku pembangunan, dalam hal ini pemerintah dan masyarakat dapat menjaga keseimbangan alam dari setiap proses pembangunan yang dilakukannya. Wujud nyata dari konsep pembangunan tersebut adalah usaha-usaha yang bertalian dengan konservasi lingkungan (Tambunan, 2008).

Kajian tentang masyarakat dan lingkungan sudah banyak dikemukakan oleh para akademisi. Persepsi masyarakat tentang lingkungan salah satunya dikemukakan oleh Kusna Haddi Nugraha (2009) dalam Jurnal Ilmu Lingkungan yang berjudul "Hubungan Antara Persepsi Masyarakat tentang $\mathrm{Ru}-$ ang Terbuka Hijau dan Etika Lingkungan dengan Partisipasi Masyarakat dalam Pengembangan Kota yang Berwawasan Ling- kungan". Dalam penelitiannya Nugraha menggunakan pendekatan kuantitatif untuk mengukur persepsi masyarakat dan partisipasi masyarakat berkenaan dengan pengembangan Kota Bogor yang berwawasan lingkungan. Penelitian ini dilaksanakan di Kecamatan Bogor Tengah Kota Bogor pada tahun 2008 dengan jumlah sampel sebanyak 40 orang yang diambil secara proportional random sampling. Metode yang digunakan yaitu dengan menggunakan metode survai dan teknik analisis data dengan menggunakan uji statistik korelasi dan regresi linear sederhana serta korelasi dan regresi linear ganda.

Hasil penelitian ini menghasilkan tiga kesimpulan yaitu: (1) terdapat hubungan positif yang sangat signifikan antara persepsi masyarakat tentang ruang terbuka hijau dengan partisipasi masyarakat dalam pengembangan kota yang berwawasan lingkungan; (2) terdapat hubungan positif yang signifikan antara etika lingkungan dan partisipasi masyarakat dalam pengembangan kota yang berwawasan lingkungan dan; (3) terdapat hubungan positif yang sangat signifikan antara persepsi masyarakat tentang ruang terbuka hijau dan etika lingkungan secara bersamasama dengan partisipasi masyarakat dalam pengembangan kota yang berwawasan lingkungan. Simpulan dari penelitian ini bahwa partisipasi masyarakat dalam pengembangan kota yang berwawasan lingkungan dapat ditingkatkan melalui persepsi masyarakat tentang ruang terbuka hijau dan etika lingkungan secara bersamasama.

Sebagai bagian dari pelaku pembagunan, Universitas Negeri Semarang (Unnes) memiliki andil dan tanggung jawab yang cukup besar dalam upaya-upaya konservasi tersebut. Bentuk responsibilitas ini diwujudkan dalam visinya yakni, mendukung akselerasi Unnes sebagai Universitas Konservasi yang Sehat Unggul dan Sejahtera dan Bertaraf Internasional. Konsekuensi dari visi tersebut adalah seluruh gerak dan aktifitas yang dilakukan oleh Unnes haruslah berdimensi konservasi lingkungan. Tidak hanya itu, Unnes juga harus menjadi avant garde bagi usahausaha konservasi, baik antar perguruan tinggi, maupun pada masyarakat sekitarnya.

Masyarakat sebagai sumber daya ma- 
nusia dalam menghadapi lingkungan perlu memiliki tingkat keberdayaan yang tinggi dalam beradaptasi di lingkungan apapun (Mulyadi, 2009). Begitu pula pada masyarakat Sekaran, Kecamatan Gunung Pati, Kota Semarang, merupakan masyarakat yang setiap hari berdialektika secara langsung oleh seluruh civitas akademika dan karyawan Unnes. Pada tataran idealitasnya, visi konservasi lingkungan yang diusung oleh Unnes ini harus berpengaruh pada masyarakat sekitarnya. Tetapi di sisi lain, masyarakat Sekaran juga merupakan entitas yang memiliki sistem pengetahuan, sistem budaya dan sistem sosial sendiri. Sebagai masyarakat yang berbasis pada pertanian, masyarakat Sekaran tentu memiliki persepsi tersendiri tentang konservasi lingkungan. Untuk itulah dalam tulisan ini akan diuraikan mengenai persepsi masyarakat Sekaran mengenai konservasi lingkungan.

Konservasi merupakan suatu upaya yang dilakukan oleh manusia untuk melestarikan lingkungannya. Dalam Antropologi Ekologi, kajian tentang konservasi berfokus pada pola hubungan antara manusia dan lingkungannya, sebab keduanya merupakan satu ekosistem yang saling mempengaruhi. Manusia dapat mempengaruhi alam dengan cara mengolah dan mengeksploitasinya, tetapi sebaliknya, lingkungan dengan segala perubahan yang terjadi di dalamnya juga dapat mempengaruhi pola hidup manusia.

Menurut Edmund Leach, lingkungan bukanlah benda alami, ia merupakan seperangkat pemahaman, suatu produk kebudayaan, dan soal persepsi. Hubungan antara suatu masyarakat dengan lingkungannya hanya dapat dipahami bila kita menyimak cara pengorganisasian lingkungan itu dalam kategori-kategori verbal yang disusun oleh mereka yang menggunakannya (Kaplan, 2002:107). Berkaitan dengan persepsi, maka kebudayaan yang dimiliki oleh suatu masyarakat merupakan model-model kognitif yang terwujud dalam serangkaian aturan, strategi, dan petunjuk yang dipergunakan oleh manusia untuk menghadapi lingkungannya.

Pengetahuan dapat diperoleh dari hasil hubungan langsung dengan lingkungan alam itu sendiri maupun kontak dengan individu- individu di sekitarnya berua informasi yang disampaikan melalui simbol, baik lisan maupun tertulis yang berisi kategori-kategori, strategi-strategi untuk berhadapan dengan lingkungan tertentu atau memanfaatkannya (Ahimsa-Putra, 1986:4). Dengan demikian, lingkungan yang efektif ialah lingkungan sebagaimana yang dikonseptualisasikan, dimanfaatkan, dan dimodifikasi oleh manusia (Kaplan, 2002:107).

Hubungan timbal balik antara manusia dan lingkungan dalam kajian ekologi budaya dimaknai sebagai pola adaptasi, yakni cara sesuatu budaya memanfaatkan lingkungan. Julian Steward menyatakan bahwa perilaku adaptif manusia dapat dijelaskan dengan memahami organisasi kerja dan teknologi yang digunakan dalam interaksi antara manusia dan lingkungan. Tetapi hubungan ini tidaklah secara langsung melainkan diantarai oleh nilai-nilai, pengetahuan, kepercayaan yang membentuk suatu pola budaya (Laksono, 2001:13). Dengan menggunakan ekologi budaya, maka perhatian tentang adaptasi dapat dilihat dalam dua tataran yakni pertama adalah cara system budaya beradaptasi terhadap lingkungan totalnya dan kedua adalah perhatian terhadap cara institusi-institusi dalam suatu budaya beradaptasi dan saling menyesuaikan diri (Kaplan, 2002:102).

Untuk menganalisis hubungan manusia dan lingkungannya, Steward mengusulkan tiga langkah dasar, yakni: Pertama, melakukan analisis atas hubungan antara lingkungan dan teknologi pemanfaatan dan produksi. Kedua, melakukan analisis atas "pola-pola perilaku" terhadap eksploitasi suatu kawasan tertentu yang menggunakan teknologi tertentu. Ketiga, melakukan analisis atas tingkat pengaruh dari pola-pola perilaku dalam pemanfaatan lingkungan terhadap aspek-aspek lain dari kebudayaan (Poerwanto, 2000:69, Ahimsa-Putra, 1994:4).

Dengan demikian, kajian tentang Persepsi masyarakat Sekaran tentang konservasi lingkungan dapat dianalisis melalui pola adaptasinya terhadap lingkungan. Persepsi dalam hal ini dimaknai sebagai pandangan, pengamatan atau tanggapan orang terhadap suatu benda, kejadian, tingkah laku manusia, atau hal-hal yang ditemui sehari-hari. Persep- 
si tersebut antara lain ditentukan oleh proses sensori yang bisa kita gunakan (penglihatan dan pendengaran), penilaian, dan interpretasi yang didasarkan pada pengalaman-pengalaman masa lalu (Laksono, 2001:14).

\section{METODE PENELITIAN}

Tulisan ini berdasar pada hasil penelitian yang menggunakan metode kualitatif. Metode kualitatif merupakan prosedur penelitian yang menghasilkan data deskriptif berupa kata-kata tertulis atau lisan dari orang-orang dan perilaku yang dapat diamati. Metode kualitatif deskriptif digunakan untuk mempelajari dan menerangkan kasus secara natural.

Penelitian ini dilaksanakan di Kelurahan Sekaran, Kecamatan Gunungpati, Kota Semarang. Lokasi penelitian ini berada di sekitar Kampus Universitas Negeri Semarang (Unnes) Sekaran sehingga mudah dijangkau ketika pengambilan data. Adapun alasan pemilihan Kelurahan Sekaran sebagai lokasi penelitian dikarenakan lokasi ini tepat dimana terdapat masyarakat yang bersinggungan langsung dengan keberadaan Unnes yang telah membawa perubahan di lingkungan mereka. Selain itu, Unnes yang mengusung visi konservasi dalam pengembangan kelembagaannya. Teknik observasi merupakan kegiatan yang pemusatan perhatian terhadap suatu obyek dengan menggunakan seluruh alat indera. Hal-hal yang observasi dalam penelitian ini tidak lepas dari fokus penelitian di atas yaitu kondisi lingkungan masyarakat Sekaran, pola perilaku masyarakat dalam mengelola dan menjaga lingkungan. Dalam pengumpulan data melalui teknik observasi ini, peneliti menggunakan alat bantu yaitu catatan lapangan.

\section{HASIL DAN PEMBAHASAN}

Kelurahan Sekaran merupakan salah satu kelurahan yang secara administratif berada di Kecamatan Gunungpati, Kota Semarang Provinsi Jawa Tengah. Sebelum bergabung dengan Kota Semarang, Kelurahan Sekaran dahulu merupakan bagian dari wilayah Kabupaten Semarang yang berpusat di
Ungaran. Secara geografis, letak Kelurahan Sekaran cukup strategis sebab diapit oleh 2 (dua) pusat pemerintahan Kabupaten/Kota. Jarak Kelurahan Sekaran dengan Ungaran, ibukota Kabupaten Semarang adalah sekitar $9 \mathrm{~km}$ sedangkan dari Kota Semarang sebagai pusat pemerintahan Kota Semarang sekaligus sebagai ibukota Provinsi Jawa Tengah hanya berjarak $8 \mathrm{~km}$.

Luas wilayah Kelurahan Sekaran adalah 490,718 Ha yang terdiri atas 7 (tujuh) Rukun Warga (RW) dan 26 RT (Rukun Tetangga). Ketika masih berstatus sebagai bagian dari Kabupaten Semarang, wilayah ini terbagi atas 5 dusun yaitu Kampung Sekaran, Kampung Banaran, Bantar Dowo, Bangkong, dan Persen. Namun seiring dengan perpidahan status dari desa menjadi kelurahan, maka status administratif dusun digantikan oleh satuan administratif RW (Rukun Warga).

Secara topografis, Kelurahan Sekaran memiliki wilayah yang berbukit-bukit dengan ketinggian tanah dari permukaan laut sekitar $75 \mathrm{~m}$. Dengan kondisi wilayah yang demikian, maka pepohonan yang hijau masih tampak tersebar di Sekaran di sela-sela pemukiman penduduk yang mulai padat. Di Keluarah Sekaran, juga terdapat tanah bekas bondo desa seluas $159.950 \mathrm{Ha}$. Tanah inilah yang sebagain besar dipergunakan untuk pembangunan Kampus IKIP Semarang yang sekarang berubah nama menjadi Universitas Negeri Semarang (Unnes).

Kelurahan Sekaran berada di wilayah administratif Kecamatan Gunungpati yang berdasarkan data monografi desa tahun 2010 memiliki jumlah penduduk 6.241 orang. Jumlah penduduk Sekaran berdasarkan komposisi jenis kelamin terdapat 3.195 laki-laki, 3.046 perempuan dengan jumlah Kepala Keluarga 1.542 orang. Dari gambaran jumlah tersebut dapat dikatakan komposisi antara penduduk laki-laki dan penduduk perempuan cukup seimbang.

Dari segi agama, mayoritas penduduk Sekarang menganut Agama Islam yaitu sebanyak 6.217 orang atau sekitar 99,6\% dari keseluruhan penduduk Sekaran. Sisanya sebanyak 24 orang menganut agama Katolik.

Berdasarkan komposisi usia produk- 
tif - non produktif, maka jumlah penduduk Sekaran terbagi dalam tiga kelompok usia yaitu: (1) usia sekolah antara 4-19 tahun berjumlah 1.697 orang; (2) usia tenaga kerja antara 20-60 tahun berjumlah 4.060 orang; dan (3) usia lanjut yaitu 60 tahun keatas berjumlah 317 orang. Dari usia produktif tersebut tersegmentasi kedalam beberapa mata pencaharian penduduk yang mayoritas sebagai petani dan pedagang.

Letak geografis Kelurahan Sekaran yang berada di pinggiran Kota Semarang dan topografinya yang bergelombang, menjadikan aktifitas masyarakat Sekaran sebagian besar berada di wilayah pertanian. Berdasarkan data monografi desa tahun 2010, jumlah penduduk berdasarkan mata pencaharian terdapat pada Tabel 1.

Tabel 1. Jumlah Penduduk Berdasarkan Mata Pencaharian

\begin{tabular}{ll}
\hline \multicolumn{1}{c}{ Mata pencaharian } & Jumlah \\
\hline Petani & 917 \\
Wiraswasta (pedagang) & 789 \\
Karyawan & 482 \\
Pertukangan & 392 \\
Buruh & 148 \\
Jasa & 122 \\
Pensiunan & 26 \\
Jumlah & 2876 \\
\hline
\end{tabular}

Sumber: Data Monografi Kelurahan Sekaran, 2010.

Sebagian besar penduduk Sekaran bermatapencaharian sebagai petani dan pedagang, lalu disusul mata pencaharian lain seperti: karyawan, pertukangan, buruh dan jasa. Pekerjaan penduduk Sekaran saat ini mengalami diversifikasi jika dibandingkan dengan kondisi dahulu. Dahulu penduduk Sekaran hanya sebagai petani dan pedagang.

Gambaran masyarakat Sekaran diatas berdasarkan data monografi tahun 2010, akan tetapi jauh menilik ke belakang diketahui bahwa kondisi Sekaran jauh berbeda dengan saat ini. Salah satu faktor perubahan adalah berdirinya IKIP Semarang yang sekarang berganti nama menjadi Universitas Negeri Semarang (Unnes) yang berlokasi di
Kelurahan Sekaran, Kecamatan Gunungpati. Unnes yang mulai tahun 1987-an masuk ke wilayah Sekaran untuk pembebasan lahan dan gedung-gedung mulai didirikan pada tahun 1990-1991 menjadi penanda adanya fase perubahan kondisi masyarakat Sekaran secara keseluruhan. Keberadaan Unnes sebagai institusi pendidikan tinggi memberikan pengaruh yang besar bagi penduduk Sekaran. Pengaruh tersebut terasa dalam berbagai aspek kehidupan masyarakat secara sosial, budaya dan ekonomi.

Jauh sebelum Unnes datang, kondisi Sekaran masih berupa bukit-bukit yang dimanfaatkan masyarakat sebagai lahan pertanian. Sebagian besar penduduk bermata pencaharian sebagai petani dan pedagang. Sebagaimana yang diungkapkan oleh Pak Fauzan, 65 tahun, seorang petani berikut ini:

"Penduduk sini itu dulu mayoritas bertani dan berdagang. Kalo merantau ke Jakarta jadi pedagang buah di sana. Orang sini itu memang terkenal sebagai pedagang buah kalo di Jakarta".

Disesuaikan dengan topografi Sekaran maka, pertanian di daerah ini bukanlah pertanian sawah melainkan tanaman keras seperti: pepaya, singkong, pisang, sengon dan sebagainya. Hingga saat ini lahan-lahan pertanian penduduk masih ada meski berada di luar Sekaran. Hal ini dikarenakan tidak ada lagi lahan pertanian di wilayah Sekaran. Lahan di wilayah Sekaran sudah beralih fungsi untuk lahan usaha disesuaikan dengan kebutuhan warga Unnes.

Setelah tahun 1990-an atau setelah Unnes berdiri di Kelurahan Sekaran, menyusul infrastruktur jalan aspal, angkutan transportasi, jaringan komunikasi dan lain sebagainya sebagai awal dari perubahan sosial yang ada di Sekaran. Jika dahulu sebelum ada jalan aspal, sangat susah untuk menjangkau daerah Sekaran dikarenakan jalan tanah yang sempit dan becek apabila musim hujan datang. Akses air bersih juga sulit, untuk mencari air bersih harus menempuh jarak yang cukup jauh dengan medan yang sulit.

Setelah Unnes berdiri maka mulai ber- 
kembanglah pusat keramaian di Sekaran. Mahasiwa yang datang dari berbagai daerah untuk kuliah dan para pendatang yang mendirikan usaha di daerah kampus turut menambah jumlah kepadatan penduduk di daerah Sekaran. Hal ini dialami langsung oleh Bapak Fauzan, yang dahulu ketika Unnes mulai berdiri, beliau menjadi mandor bangunan kemudian juga mencarikan kos-kosan bagi mahasiswa. Beliau juga mengatakan bahwa pembangunan Sekaran ini turut "memanggil" para perantau yang semula berdagang buah di Jakarta untuk kembali pulang dan mencari peruntungan di daerah sendiri.

Bapak Fauzan menguraikan kronologis bagaimana Sekaran bisa menjadi seperti sekarang ini yang dipadati oleh mahasiswa, pendatang dan berbagai macam usaha yang hampir tidak menyisakan tanah kosong sejengkalpun. Hukum alam bahwa ketika suatu intitusi pendidikan tinggi berdiri maka akan diikuti dengan berdirinya pusat keramaian baru. Itu pula yang terjadi di Sekaran, setelah Unnes berdiri, mahasiswa sudah mulai melakukan kegiatan di Kampus Sekaran, maka muncullah berbagai macam bidang usaha guna memenuhi kebutuhan mahasiswa, seperti: kos-kosan, fotokopi, warung makan, dan toko kelontong. Masyarakat Sekaran yang persis berada di sekitar kampus seharusnya dapat menangkap peluang usaha tersebut lalu memanfaatkannya. Bapak Fauzan mengatakan, yang terjadi justru sebaliknya, masyarakat Sekaran merasa terjepit diantara hiruk pikuk perkembangan di Sekaran. Peluang usaha itu justru dimanfaatkan oleh orang-orang diluar Sekaran atau pendatang.

Masyarakat Sekaran rata-rata memiliki tanah yang dengan itu mereka manfaatkan sebagai lahan pertanian. Ketika Unnes berkembang, mereka sebenarnya ingin ikut memanfaatkan peluang yang ada akan tetapi, keterbatasan pengetahuan dan wawasan mereka yang membuat mereka tidak mengetahui bagaimana cara memanfaatkan peluang tersebut. Faktor pendidikan yang rendah inilah yang kemudian oleh Bapak Fauzan ditegaskan:

"Masyarakat sini itu ya pengen pu- nya usaha kos-kosan atau warung tapi mereka itu gak tahu caranya. Bikin kos-kosan sudah hutang ke bank tapi kosnya gak laku trus bangkrut. Bikin warung makan tapi lauknya itu-itu saja, akhirnya ya gak laku to. Melihat kayak gitu akhirnya masyarakat itu terjepit, ya sudah akhirnya dijual saja tanahnya, mereka ada yang pindah ke daerah lain. Mereka itu karena pendidikannya rendah, gak punya wawasan makanya gak tahu gimana caranya untuk buat usaha, tahunya ya jual tanah."

Dari segi pendidikan, penduduk Sekaran memiliki tingkat pendidikan yang masih rendah. Sebagian besar hanya mengenyam pendidikan dasar, sehingga pekerjaan yang dapat dilakoni seperti pedagang dan petani yang tidak memerlukan pendidikan formal yang tinggi. Masyarakat Sekaran belum memiliki pemahaman akan pentingnya pendidikan bagi anak-anak mereka. Dari gambaran pendidikan tersebut menjadi faktor bahwa mereka tidak memiliki pengetahuan dan wawasan untuk mengetahui cara mengembangkan diri mereka sendiri. Faktor pendidikan ini pula yang turut andil dalam keterpinggiran masyarakat Sekaran di lingkungan mereka sendiri.

Dari kondisi tersebut, masyarakat Sekaran sering disebut sebagai "tuan tanah" karena banyaknya tanah-tanah yang mereka jual. Dari tahun ke tahun, harga tanah di wilayah Sekaran mengalami kenaikan harga. Menjual tanah adalah salah satu perubahan ekonomi bagi masyarakat Sekaran. Bukannya tanah tersebut dimanfaatkan untuk lahan pertanian atau usaha lain yang lebih menghasilkan, melainkan mereka memilih untuk menjual tanahnya. Bagi mereka menjual tanah itu lebih mudah dan menghasilkan uang secara cepat.

Keberadaan Unnes ditengah masyarakat Sekaran telah membawa perubahan dalam aspek kehidupan masyarakat baik disadari maupun tidak. Pembangunan gedung-gedung baru dan perkembangan Unnes secara institusional membawa dampak bagi masyarakat sekitar yaitu Sekaran. Dam- 
pak yang berupa perubahan secara sosial, budaya dan ekonomi. Peluang usaha pastinya terbuka lebar dengan adanya peningkatan jumlah mahasiswa setiap tahunnya. Peluang ini tidak saja dimanfaatkan oleh masyarakat Sekaran saja tapi justru masyarakat pendatang lebih jeli dan pintar dalam memanfaatkan peluang tersebut.

Pada tahun 2010 ini, Unnes mencanangkan dirinya sebagai Universitas Konservasi. Konservasi yang dimaknai Unnes tidak hanya pada aspek lingkungan tapi juga aspek moral dan budaya. Menilik pada kata konservasi sendiri identik dengan pelestarian lingkungan. Berkaitan dengan hal itu, perlu diketahui tentang persespsi masyarakat Sekaran tentang konservasi lingkungan.

Topografi daerah Sekaran menjadikan sebagian besar penduduknya bermata pencaharian sebagai petani. Petani adalah orang yang paling dekat dengan alam. Pola perilaku petani berhubungan erat dan selalu dikaitkan dengan alam. Sebagaimana yang dikemukakan oleh Edmund Leach (dalam Kaplan, 2001) bahwa lingkungan bukanlah benda alami, ia merupakan seperangkat pemahaman, suatu produk kebudayaan, dan soal persepsi. Demikian halnya dengan petani Sekaran yang secara karakteristik bukanlah petani sawah melainkan petani ladang, sehingga mereka memiliki persepsi atau pemaknaan yang lebih sederhana mengenai lingkungan alam.

Tanaman yang menjadi komoditas masyarakat Sekaran adalah tanaman buah dan kayu sengon, seperti: singkong, pisang kluthuk, pepaya, durian, dan sebagainya. Perilaku petani Sekaran dalam mengelola lahannya sudah modern, misalnya dengan penggunaan pupuk semprot (pestisida) bukan pupuk kandang. Persepsi mereka tentang konservasi lingkungan sangatlah sederhana, bahwa ternyata mengolah lahan pertanian sebagai aktifitas mereka sehari-hari merupakan bagian dari upaya mereka dalam melestarikan lingkungan.

Perkembangan daerah Sekaran dengan keberadaan Kampus Unnes Sekaran telah merubah persepsi mereka tentang lingkungan alam (tanah). Perubahan persepsi tersebut sebagai cara masyarakat beradaptasi dengan perubahan lingkungan yang terjadi setelah pembangunan Unnes. Dalam kajian ekologi budaya, pola adaptasi manusia dengan lingkungan adalah cara sesuatu budaya memanfaatkan lingkungan. Laksono (2001: 14) mengatakan bahwa persepsi tersebut antara lain ditentukan oleh penglihatan, pendengaran, penilaian, dan interpretasi yang didasarkan pada pengalaman-pengalaman masa lalu.

Masyarakat Sekaran dari pengalaman mereka sebelum dan sesudah pembangunan Unnes dapat menyesuaikan diri dengan lingkungan yang baru. Mereka tidak lagi memandang tanah sebagai sumber penghidupan mereka yang harus mereka jaga dan lestarikan, melainkan sebuah komoditas yang dapat mendatangkan uang. Hal ini terbukti dengan sebagian masyarakat Sekaran dan sekitarnya yang memilih untuk menjual tanah mereka kepada pendatang, yang oleh pendatang biasanya dipergunakan untuk tempat kos maupun usaha lain yang dibutuhkan oleh mahasiswa. Terlebih tidak membutuhkan waktu lama bagi masyarakat Sekaran untuk menjual tanahnya karena selalu ada orang yang berminat untuk membeli tanah di Sekaran dengan harga yang tinggi.

Dari perubahan persepsi tentang alam tersebut menggiring mereka pada perubahan persepsi tentang konservasi lingkungan atau cara mereka memandang pelestarian lingkungan tersebut. Masyarakat Sekaran berada dalam suatu arus kekurangpedulian terhadap kelestarian lingkungan dimulai dari hal kecil dan mereka terbawa oleh arus itu. Mereka tidak lagi memandang bahwa menjaga kebersihan lingkungan suatu hal yang penting yang harus dilakukan dan menjadi tanggung jawab bersama seluruh warga. Akibatnya, mereka dalam tahap menganggap kebersihan lingkungan diserahkan pada pihak yang berkepentingan saja, misalnya: dinas kebersihan kota ataupun perangkat desa. Mereka hanya mengurusi kebersihan lingkungan rumah mereka saja.

Dari segi lingkungan yang dekat dengan pemukiman, Bapak Fauzan melihat adanya penurunan kualitas kebersihan lingkungan yang terjadi saat ini: "Kalo masalah lingkungan ya, daerah sini itu lebih bersih 
dulu ketimbang sekarang. Penduduknya semakin padat tapi tidak peduli dengan sampah, bahkan di pertigaan situ kalo hujan deras ya banjir. Kesadaran untuk membersihkan lingkungan kok kurang."

Seiring dengan perkembangan daerah Sekaran ini, maka secara perlahan telah menurunkan kualitas lingkungan. Masyarakat baik penduduk asli Sekaran, mahasiswa, dan pendatang sudah tidak peduli dengan pemeliharaan lingkungan bersama. Bagi masyarakat Sekaran, konservasi lingkungan sebagaimana yang dicanangkan Unnes bukanlah sesuatu yang penting. Pemaknaan tentang konservasi lingkungan lebih bersifat personal bagi masing-masing individu yang ada di Sekaran, tidak hanya penduduk asli Sekaran, tapi juga pendatang dan mahasiswa.

Bagi masyarakat Sekaran, konservasi lingkungan sebagaimana yang dicanangkan Unnes bukanlah sesuatu yang penting. Pemaknaan tentang konservasi lingkungan lebih bersifat personal bagi masing-masing individu yang ada di Sekaran, tidak hanya penduduk asli Sekaran, tapi juga pendatang dan mahasiswa.

Persepsi masyarakat Sekaran tentang konservasi lingkungan tidak lepas dari sistem pengetahuan dan perubahan sosial yang terjadi dalam kehidupan mereka. Sebagai masyarakat desa yang bersahaja layaknya kehidupan masyarakat agraris di pedesaan Jawa pada umumnya, masyarakat Sekaran merupakan masyarakat yang dekat dengan alam. Sebelum tahun 1991, kehidupan mereka tidak lepas dari aktifitas mengolah alam yang sekaligus merupakan sumber mata pencaharian mereka, baik sebagai produsen (petani) maupun sebagai distributor (pedagang). Dengan topografi yang berbukit dan sumber air yang kurang, menjadikan masyarakat Sekaran hidup dalam sistem pertanian lahan kering dengan produk pertanian berupa padi gogo (padi tegalan), kayu jati dan sengon, dan berbagai jenis buah-buahan.

Aktifitas pertanian ini juga didukung oleh lahan yang luas. Selain memiliki lahan garapan, masyarakat Sekaran juga dapat mengakses dan mengolah tanah gege, yakni tanah milik Negara tetapi tidak bersertifikat. Selain itu, juga terdapat tanah bondo desa yang diperuntukkan bagi Kepala Desa, tetapi bisa mereka kerjakan sebagai petani penggarap. Semua hasil pertanian ini merupakan sumber utama penunjang ekonomi keluarga mereka. Kondisi inilah yang menyebabkan tingkat dependesi mereka terhadap alam sangat tinggi. Transformasi nilai akan pentingnya menjaga kelestarian alam dan kebersihan lingkungan kerap mereka lakukan melalui ritual dan aktifitas budaya yang mereka selenggarakan. Mulai dari nyadran, bersih desa, hingga pada pagelaran wayang semalam suntuk untuk memotivasi dan menyemangati warga desa dalam mewujudkan keharmonisan dalam kehidupan mereka, termasuk keharmonisan dengan alam. Dengan cara yang seperti ini disertai dengan pola hidup dan mata pencaharaian yang homogen, membuat masyarakat Sekaran memiliki kesadaran yang bersifat komunal akan kewajiban menjaga kelestarian alam.

Tetapi pada tahun 1991 seiring dengan dibangunnya Kampus IKIP Semarang yang sekarang berganti nama menjadi Universitas Negeri Semarang (Unnes), terjadi perubahan pada pola hidup masyarakat Sekaran. Lahan bondo desa, tanah gege, dan beberapa lahan milik warga dibeli dan dilepaskan untuk pembangunan Kampus IKIP Semarang. Pembelian dan pelepasan lahan ini sebenarnya sudah dilakukan sejak tahun 1987-1988, tetapi masyarakat masih bisa menggarapnya selama gedung kampus belum dibangun. Sejak saat itu, lahan pertanian warga mulai menyempit dan aktifitas bertani pun mulai berkurang. Warga desa banyak yang mengubah mata pencaharian mereka ke non pertanian, berupa jasa atau buruh bangunan.

Dari tahun ke tahun, Universitas Negeri Semarang mengalami perkembangan yang cukup pesat. Berbagai mahasiswa dan dosen yang datang dari berbagai daerah tinggal dan menetap di Sekaran. Interaksi sosial yang terjadi antara masyarakat pendatang dengan masyarakat Sekaran sedikit banyak memberikan nilai-nilai baru bagi kedua belah pihak. Bagi masyarakat Sekaran, kedatangan para pendatang (mahasiswa dan dosen) secara perlahan mengubah cara pandang mereka terhadap mata pencaharian. Jika dahulu pendapat mereka sangat bergantung pada hasil 
alam (hasil pertanian), maka saat ini mereka mulai berfikir bahwa pendapatan dan peningkatan ekonomi keluarga tidak lagi bersumber pada hasil alam semata, tetapi pada sektor jasa seperti warung makan dan rumah sewa (kos-kosan). Beberapa lahan pertanian pun yang dahulu merupakan kebun, dijadikan kos-kosan, atau dijual bagi pendatang yang berminat untuk membelinya.

Pergeseran cara pandang akan sumber ekonomi dan sumber penghidupan mereka mengakibatkan terjadinya pergeseran akan persepsi mereka tentang konservasi lingkungan. Lingkungan/alam yang dahulu mereka olah untuk kebutuhan pangan dan peningkatan ekonomi keluarga, kini menjadi komoditas yang bisa mendatangakan keuntungan tanpa harus diolah. Hal ini pula yang mengakibatkan sistem mata pencaharian mereka semakin heterogen. Demikian pula pada kehidupan sosial mereka yang telah bercampur dengan pendatang, lebih terbuka dan dinamis. Akan tetapi hal ini membawa beberapa implikasi bagi masyarakat Sekaran. Ritual komunal yang dahulu sering mereka praktikkan sudah tidak ada lagi, sehingga transformasi nilai-nilai konservasi yang kerap mereka lakukan melalui media aktifitas budaya ini tidak bisa lagi dilakukan. Hal inilah yang menjadikan tanggung jawab akan kelestarian lingkungan tidak lagi bersifat komunal, tetapi diserahkan pada masing-masing orang atau lebih bersifat personal. Aktifitas konservasi lingkungan hanya sebatas aktifitas rumah tangga yang hanya dimaknai sebagai bersih-bersih lingkungan. Ritual komunal dan kegiatan budaya telah tergantikan dengan rutinitas kerja bakti yang dikoordinir oleh Ketua RT masing-masing. Dengan demikian, perubahan social yang terjadi dalam kehidupan masyarakat Sekaran sangat berpengaruh pada persepsi dan aktifitas konservasi lingkungan mereka.

Persepsi masyarakat Sekaran tentang konservasi lingkungan tidak lepas dari sistem pengetahuan dan perubahan sosial yang terjadi dalam kehidupan mereka. Dengan mendasarkan analisis pada antropologi ekologi, maka kajian tentang konservasi dapat dilihat pada pola hubungan antara manusia dan lingkungannya, sebab keduanya me- rupakan satu ekosistem yang saling mempengaruhi (Nugraha, 2009). Manusia dapat mempengaruhi alam dengan cara mengolah dan mengeksploitasinya, tetapi sebaliknya, lingkungan dengan segala perubahan yang terjadi di dalamnya juga dapat mempengaruhi pola hidup manusia.

Jika dikaitkan dengan teori Steward tentang hubungan manusia dengan lingkungan yang dapat dilihat pada pemanfaatan teknologi dan produksi, pola-pola perilaku, serta pengaruh pola perilaku pada pemanfaatan lingkungan (Poerwanto, 2000:69, Ahimsa-Putra, 1994:4), maka persepsi masyarakat Sekaran tentang konservasi yang terbangun dapat dilihat pada ketiga aspek tersebut. Pergeseran pola penghidupan dan teknologi hidup yang dimiliki oleh masyarakat Sekaran turut berpengaruh pada pola-pola perilaku mereka dengan lingkungan.

Sebagai masyarakat desa yang bersahaja layaknya kehidupan masyarakat agraris di pedesaan Jawa pada umumnya, masyarakat Sekaran merupakan masyarakat yang dekat dengan alam. Sebelum tahun 1991, kehidupan mereka tidak lepas dari aktifitas mengolah alam yang sekaligus merupakan sumber mata pencaharian mereka, baik sebagai produsen (petani) maupun sebagai distributor (pedagang). Dengan topografi yang berbukit dan sumber air yang kurang, menjadikan masyarakat Sekaran hidup dalam sistem pertanian lahan kering dengan produk pertanian berupa padi gogo (padi tegalan), kayu jati dan sengon, dan berbagai jenis buah-buahan.

Aktifitas pertanian ini juga didukung oleh lahan yang luas. Selain memiliki lahan garapan, masyarakat Sekaran juga dapat mengakses dan mengolah tanah gege, yakni tanah milik Negara tetapi tidak bersertifikat. Selain itu, juga terdapat tanah bondo desa yang diperuntukkan bagi Kepala Desa, tetapi bisa mereka kerjakan sebagai petani penggarap. Semua hasil pertanian ini merupakan sumber utama penunjang ekonomi keluarga mereka. Kondisi inilah yang menyebabkan tingkat dependesi mereka terhadap alam sangat tinggi. Transformasi nilai akan pentingnya menjaga kelestarian alam dan kebersihan lingkungan kerap mereka lakukan melalui ritual dan aktifitas budaya yang 
mereka selenggarakan. Mulai dari nyadran, bersih desa, hingga pada pagelaran wayang semalam suntuk untuk memotivasi dan menyemangati warga desa dalam mewujudkan keharmonisan dalam kehidupan mereka, termasuk keharmonisan dengan alam. Dengan cara yang seperti ini disertai dengan pola hidup dan mata pencaharaian yang homogen, membuat masyarakat Sekaran memiliki kesadaran yang bersifat komunal akan kewajiban menjaga kelestarian alam.

Muryani (2011) menyatakan dalam hasil penelitiannya bahwa pergeseran cara pandang akan sumber ekonomi dan sumber penghidupan mereka mengakibatkan terjadinya pergeseran akan persepsi mereka tentang konservasi lingkungan. Lingkungan/ alam yang dahulu mereka olah untuk kebutuhan pangan dan peningkatan ekonomi keluarga, kini menjadi komoditas yang bisa mendatangakan keuntungan tanpa harus diolah. Hal ini pula yang mengakibatkan sistem mata pencaharian mereka semakin heterogen. Demikian pula pada kehidupan sosial mereka yang telah bercampur dengan pendatang, lebih terbuka dan dinamis. Akan tetapi hal ini membawa beberapa implikasi bagi masyarakat Sekaran. Ritual komunal yang dahulu sering mereka praktikkan sudah tidak ada lagi, sehingga transformasi nilainilai konservasi yang kerap mereka lakukan melalui media aktifitas budaya ini tidak bisa lagi dilakukan. Hal inilah yang menjadikan tanggung jawab akan kelestarian lingkungan tidak lagi bersifat komunal, tetapi diserahkan pada masing-masing orang atau lebih bersifat personal. Aktifitas konservasi lingkungan hanya sebatas aktifitas rumah tangga yang hanya dimaknai sebagai bersih-bersih lingkungan. Ritual komunal dan kegiatan budaya telah tergantikan dengan rutinitas kerja bakti yang dikoordinir oleh Ketua RT masing-masing. Dengan demikian, perubahan sosial yang terjadi dalam kehidupan masyarakat Sekaran sangat berpengaruh pada persepsi dan aktifitas konservasi lingkungan mereka.

\section{SIMPULAN}

Simpulan dari penelitian ini adalah bahwa masyarakat Kelurahan Sekaran sebelum tahun 1990-an adalah masyarakat petani dan pedagang. Mereka adalah petani ladang yang menggarap tanah negera maupun tanah pribadi dengan ditanami sengon, pisang, singkong, buah dan lain sebagainya. Sebagian yang lain sebagai pedangang di kota lain seperti Jakarta. Setelah tahun 1990an, tepatnya ketika Universitas Negeri Semarang (Unnes) datang dan menjalankan aktifitas kampus di daerah Sekaran maka, perlahan terjadi perubahan sosial pada masyarakat Sekaran. Mata pencaharian sudah mulai bervariasi, terutama di sektor jasa dan pedagang. Interaksi masyarakat Sekaran dengan warga pendatang dan mahasiswa membawa pandangan baru dan perilaku yang lebih dinamis dan terbuka.

Persepsi masyarakat Sekaran tentang konservasi lingkungan sangatlah sederhana tidak lepas dari sistem pengetahuan dan perubahan sosial yang terjadi dalam kehidupan mereka. Masyarakat Sekaran merupakan masyarakat agraris yang seluruh aktifitas kehidupan mereka tidak lepas dari mengolah alam sebagai sumber mata pencaharian mereka sebagai petani dan pedagang (distributor) hasil pertanian mereka. Setelah Unnes datang di daerah mereka maka, perlahan persepsi mereka tentang alam mulai berubah. Mata pencaharian masyarakat juga sudah mulai berubah, merambah di luar wilayah non pertanian, terutama jasa dan pedagang. Tanah yang dahulu menjadi sumber aktifitas kehidupan masyarakat mulai mereka lepaskan untuk dijual kepada pendatang yang ingin menjalankan usaha di daerah kampus. Hal ini merubah pula persepsi mereka tentang alam yaitu menjadi sebuah komoditas ekonomi yang mendatangkan keuntungan tanpa harus diolah. Konservasi lingkungan bukan menjadi hal penting dalam kehidupan masyarakat. Upaya konservasi diserahkan kepada masing-masing individu dalam masyarakat, termasuk pendatang dan mahasiswa.

Persepsi masyarakat Sekaran tentang konservasi lingkungan yang sangat sederhana tersebut kemudian diaktualisasikan melalui aktifitas kehidupan mereka seharihari. Ritual komunal yang berkaitan dengan 
konservasi lingkungan masih cukup kental, seperti: nyadran, bersih desa, wayangan yang berfungsi memotivasi warga untuk menjaga keharmonisan alam dan lingkungan. Perubahan sosial terjadi ketika masyarakat Sekaran sudah berdampingan dengan pendatang dan mahasiswa, maka aktivitas tersebut mulai ditinggalkan. Upaya yang berkaitan dengan konservasi lingkungan mengandalkan program dari pemerintah desa, seperti dari Ketua RT. Aktifitas konservasi menjadi tanggung jawab personal yang kemudian dimaknai sebagai kerja bakti atau bersih-bersih lingkungan setiap bulan.

Perubahan sosial yang terjadi pada masyarakat Sekaran yang turut mengubah persepsi dan cara pandang mereka terhadap alam. Jika dahulu konsep konservasi mereka terbangun karena relasi mereka dengan alam yang begitu dekat, maka saat ini persepsi tersebut mengalami pegeseran karena tiingkat dependensi mereka terhadap alam sudah semakin rendah. Padahal persepsi dan aktifitas konservasi yang terbangun dalam nilai-nilai dan pola hidup masyarakat harus terus dipertahankan untuk menjaga kelangsungan kehidupan manusia. Oleh karena itu sebagai univeristas yang mengusung visi konservasi, UNNES hendaknya memberikan langkah nyata bagi upaya merevitalisasi nilai-nilai konesrvasi masyarakat Sekaran.

\section{DAFTAR PUSTAKA}

Ahimsa-Putra, H.S. 1986. 'Antropologi Ekologi: Beberapa Pendekatan dan Perkembangannya". Dalam Masyarakat Indonesia: Majalah Ilmu-ilmu Sosial Indonesia, Jilid XX No.4. Jakarta

Kaplan, D. dan Robert, A.M, 2002. Teori Budaya. Yogyakarta: Pustala Pelajar.

Laksono, P.M, dkk. 2001. Igya Ser Hanjop: Masyarakat Arfak dan Konsep Konservasi. Yogyakarta: PSAP UGM, YBLBC, dan Kehati

Luthfi, A. 2010. Akses dan Kontrol Perempuan Petani Penggarap Pada Lahan Pertanian PTPN. Jurnal Komunitas, 2 (2): 9-19

Mulyadi, A. 2009. Pengembangan Sumber Daya Manusia Dalam Mendukung Konservasi Lingkungan Laguna Segara Anakan. Jurnal Pendidikan Geografi, 9 (1): 35-47

Muryani, C., dkk. 2011. Model Pemberdayaan Masyarakat dalam Pengelolaan dan Pelestarian Hutan Mangrove di Panti Pasuruan Jawa Timur. Jurnal Manusia dan Lingkungan, 5 (2): 50-60

Nugraha, K.H., Sudodo, \& Hutagalung, R.A. 2009. Hubungan Antara Persepsi Masyarakat tentang Ruang Terbuka Hijau dan Etika Lingkungan dengan Partisipasi Masyarakat dalam Pengembangan Kota yang Berwawasan Lingkungan. Jurnal Lingkungan Hidup. 1(1): 1-12

Poerwanto, H. 2000. Kebudayaan dan Lingkungan: Dalam Perspektif Antropologi. Yogyakarta: Pustaka Pelajar.

Tambunan, R. 2008. Perilaku Konservasi Pada Masyarakat Tradisional. Jurnal Harmoni Sosial. 2(2): $83-87$ 